\title{
PEsAN MORAL dalam KONTEN BeRMUATAN COUID-19 DI MEDIA SOSIAL
}

Pertama diterima : 12 Juni 2021

Bukti akhir diterima : 30 Juni 2021

\author{
Leli Nisfi Setiana', Aida Azizah² \\ Pendidikan Bahasa dan Sastra Indonesia, Fakultas Keguruan dan Ilmu Pendidikan, \\ Universitas Islam Sultan Agung Semarang \\ *Corresponding Author \\ lelinisfi@unissula.ac.id
}

\begin{abstract}
ABSTRAK
Tujuan penelitian ini adalah mengetahui pesan moral yang terdapat dalam konten di media sosial bermuatan covid-19. Mayarakat milenail saat ini telah banyak yang mampu mengekspresikan segala sesuatu berdasarkan apa yang dilihat dan dirasakannya. Seperti halnya karya sastra yang muncul sebagai bentuk ekpresi atas penciptanya. Pandemi covid-19 masih menjadi trend yang kerap muncul dalam konten-konten yang ditulis oleh mayarakat di media sosial mereka. Berbagai hal diungkapkan secara jelas, baik ungkapan tersebut terdapat berbagai bentuk nilai moral dan mengandung pesan moral yang dapat diambil. Metode penelitian ini bersifat kualitatif deskriptif dan menganalisis pesan moral yang terdapat dalam konten bermuatan covid-19 di media sosial yang dikategorikan kedalam beberapa nilai moral. Hasil penelitian menunjukkan terdapat 16 data pesan moral yang terdapat dalam tiga kategori nilai moral hubungan manusia dengan diri sendiri, hubungan manusia dengan manusia lain dan hubungan manusia dengan Tuhan.
\end{abstract}

\begin{abstract}
Abstrack
The purpose of this study was to find out the moral messages contained in the content on social media containing COVID-19. Today's millennial society has many who are able to express everything based on what they see and feel. Like a literary work that appears as a form of expression for its creator. The COVID-19 pandemic is still a trend that often appears in content written by the public on their social media. Various things are clearly stated, both these expressions contain various forms of moral values and contain moral messages that can be taken. This research method is descriptive qualitative and analyzes the moral messages contained in the covid-19 content on social media which are categorized into several moral values. The results showed there were 16 data on moral messages contained in three categories of moral values of human relations with oneself, human relations with other humans and human relationships with God.
\end{abstract}

\section{PENDAHULUAN}

Penciptaan karya sastra tidak terlepas dari sebuah imajinasi penulisnya, rangkaian cerita berupa unsur intrinsik dan ekstrinsik serta beberapa faktor pendukung lainnya. Bahasa dalam sebuah karya sastra pada dasarnya terbentuk dari hasil tulisan pengarang yang mengimplementasikan berbagai macam nilai yaitu nilai agama, nilai sosial, nilai budaya, dan nilai moral. Oleh karena itu, amanat yang disampaikan oleh pengarang adalah menjunjung tinggi nilai kebaikan khususnya merujuk ke nilai moral.

Nilai moral yang berlaku di masyarakat dapat bersifat mengikat pada setiap individu dalam kelompok masyarakat tersebut. Ada baiknya setiap individu dalam bergaul dan bersikap haruslah memperhatikan aturan 
khususnya yang ada di dalam masyarakat. Berbagai hal dapat dijadikan dasar individu dalam mengekpresikan sikapnya, terutama hal-hal yang terdapat dalam kehidupan sehari-hari. Pada masa pandemi banyak masyarakat yang mengekpresikan aspirasinya dalam berbagai bentuk, yang paling mendominasi adalah dalam berekspresi di media sosial.

Bentuk ekspresi masyarakat terhadap pandemi di dalam bermedia sosial sangatlah beragam. Beberapa dari mereka ada yang mengungkapkan dalam bentuk hal-hal yang bernilai positif dan bernilai negatif. Salah satu nilai kehidupan yang melekat pada setiap pesan yang tersirat dalam konten masyarakat di media sosial adalah berkaitan dengan nilai moral. Cakupan nilai moral meliputi seluruh persoalan kehidupan, seluruh persoalan yang menyangkut harkat dan martabat manusia. Selain itu, persoalan kehidupan manusia itu dapat dibedakan ke dalam persoalan hubungan manusia dengan diri sendiri, yang dapat berhubungan dengan masalah-masalah seperti dendam, eksistensi diri, harga, diri, rasa percaya diri, takut, maut, rindu, kesepian, dan lain-lain yang lebih bersifat melibat ke dalam diri dan kejiwaan seorang individu, hubungan manusia dengan manusia lain dalam lingkup sosial termasuk hubungan dengan lingkungan alam, yang dapat berwujud persahabatan, yang kokoh ataupun yang rapuh, kesetiaan, pengkhianatan, kekeluargaan, dan lain-lain yang melibatkan interaksi antarmanusia, serta hubungan manusia dengan Tuhannya (Nurgiyantoro, 1993: 323-325).

Berdasarkan pendapat dari Nurgiyantoro dapat diperoleh simpulan bahwa sejatinya segala tingkah laku manusia dalam kehidupan masyarakat tidak dapat lepas dari nilai moral. Banyak hal yang menjadi cakupan dalam nilai deskripsi nilai moral tersebut, akan tetapi terdapat tiga hal utama berkaitan dengan nilai moral yaitu hubungan manusia dengan diri sendiri, hubungan manusia dengan manusia lain, dan hubungan manusia dengan Tuhannya. Dari ketiga hal tersebut, banyak sekali pesan yang dapat diambi dari konten yang dituliskan oleh individu khususnya dalam menyikapi masa pandemi pada saat ini.

Menurut Susana (2016) karya sastra bukan ada hanya untuk dinikmati nilai estetikanya, akan tetapi bertugas mengurangi kerusakan moral sehingga dapat membentuk moral yang halus, manusiawi, dan berbudaya. Peneliti memilih nilai moral dalam penelitian ini, dikarenakan penanaman nilai moral sangat dibutuhkan untuk menciptakan generasi bangsa yang memiliki etika dan bermoral. Perwujudan dari generasi yang beretika dan bermoral akan sangat berpengaruh dalam kehidupan baik bagi diri sendiri, bagi kehidupan bermasyarakat menjadi lebih lebih beradab.

Menurut Brugman (2013) melakukan penelitian yang berjudul "Moral Value Evaluation: A Neglected Motivational Concept In Externalizing Behaviour Research". Hasil penelitian membahas tentang konsep motivasi evaluasi nilai moral (yaitu, atribusi pentingnya nilai-nilai moral). Berdasarkan hasil empiris sebelumnya dan kesamaan konseptual dengan konsep moral intuisi sosial penilaian, evaluasi nilai moral diharapkan menunjukkan asosiasi negatif dengan perilaku eksternalisasi. Ditemukan bahwa data secara keseluruhan mendukung kami hipotesis. Efek tidak langsung evaluasi nilai moral adalah yang terbesar kedua prediktor perilaku eksternalisasi, sedangkan motivator tidak bermoral melayani diri sendiri distorsi kognitif adalah prediktor (langsung) terbesar. Berdasarkan hasil penelitian Brugman, diperoleh bentuk persamaan penelitian yaitu persamaan dalam hal kajian mengenai nilai moral. Perbedaan hasil penelitian terletak pada objek kajian penelitian adalah berupa konten yang terdapat di media sosial bermuatan pandemi Covid-19.

Menurut Firwan (2017) melakukan penelitian berjudul "Nilai Moral Dalam Novel Sang Pencerah Karya Akmal Nasrey Basral. Hasil penelitian ini menunjukkan bahwa nilai moral dalam novel Sang Pencerah terdiri dari 4 nilai moral yaitu (1) nilai moral antara manusia dengan dirinya sendiri, terdiri atas 9 sikap yaitu, kejujuran, sabar, semangat, tanggung jawab, ikhlas, pantang menyerah, tegas, berani, dan rendah hati. (2) nilai moral antara manusia dengan manusia terdiri dari 8 sikap Sopan, peduli, tolong menolong, saling berbagi, menempati janji, menyemagati dan memotivasi, bekerja sama, dan bersosialisasi. (3) Nilai moral antara manusia dengan alam terdiri dari atas yaitu, Nasionalisme, menjaga kelestarian alam. (4) nilai moral antara manusia dengan Tuhan terdiri dari atas, yaitu bersyukur, taat beribadah dan berperasangka baik kepada Tuhan. Berdasarkan hasil penelitian Firwan, diperoleh persamaan yaitu penggunaan nilai moral sebagai kajian penelitian. Sedangkan perbedaan dengan penelitian ini adalah konten di media sosial bermuatan pandemi covid-19 sebagai objek kajian penelitiannya.

Aristiawan (2020) melakukan penelitian dengan judul "Courage And Modesty As The Attributes Of Moral Value In The Novel Of The Old Man And The Sea" . Hasil penelitian yang diperoleh adalah (1) Santiago ditentukan, menjadi pekerja keras dan ketekunan, dan optimis tentang apa ia melakukannya (2) Atribut menjadi sederhana atau kesopanan ditampilkan dalam berbagai karakteristik Santiago. Karakteristik Santiago diantaranya adalah sedang ada tidak mementingkan diri sendiri, peduli, hormat, mencintai, merasa kesepian, simpatik, dan bahkan perasaan menyesal setelah membunuh seekor ikan. Adapun persamaan dan perbedaan peneitian ini sebagai berikut:persamaannya terdapat pada objek penelitian yakni novel. Sedangkan perbedaan penelitian terdapat pada judul novel yang digunakan. Berdasarkan hasil penelitian Aristiawan, maka persamaan dengan penelitian ini adalah 
berkaitan dengan moral. Perbedaannya adalah objek kajian ini adalah novel bergenre asing, sedangkan penulis objek kajiannya adalah nilai moral dalam konten media sosial bermuatan Covid-19.

Penelitian ini menggunakan metode penelitian deskriptif kualitatif. Bogdan dan Taylor (dalam Moleong, 2010:4) bahwa metode penelitian kualitatif ini suatu prosedur yang penelitiannya menghasilkan data-data deskriptif yang berupa kata-kata tertulis atau lisan dari orang-orang dan perilaku yang dapat diamati. Penelitian ini akan mendeskripsikan data berupa kata-kata yang diamati oleh penulis terhadap nilai moral dalam konten media sosial bermuatan pandemi covid-19. Selanjutnya hasil deskripsi data tersebut akan dianalisis lebih rinci dalam pembahasan dengan deksripsi lebih runtut.

\section{PEMBAHASAN}

Hasil penelitian yang telah dilaksanakan menghasilkan data sebanyak 16 data pesan moral. Berikut penulis mendeskripisakn data penelitian berdasarkan nilai moral berdasarkan hubungan diri sendiri, hubungan dengan masyarakat dan hubungan dengan Tuhannya sebagai berikut:

Data 1/PM/WA/1.01

Kutipan: "Jadilah terang dalam kegelapan"

Pesan moral yang terdapat dalam kutipan di status WA tersebut termasuk dalam kategori hubungan manusia dengan manusia lain yaitu jadilah wanita-wanita yang tangguh di tengah pandemi, apapun itu profesimu. Seorang ibu rumah tangga jadilah Kartini untuk keluarga serta guru untuk anak di rumah. Seorang guru jadilah Kartini yang tetap berdedikasi untuk peserta didik di tengah pandemi. Seorang perawat jadilah Kartini untuk negeri membantu dan memulihkan negeri untuk terbebas dari pandemi.

Data 2: $\mathrm{PM} / \mathrm{FB} / 2.02$

Kutipan: "Kamu di rumah aja ya. Kalau haus, minum. Kalau laper, makan. Kalau di chat dibales. Jangan dibaca doang : (“"

Dari kutipan yang terdapat dalam Facebook termasuk dalam kategori pesan moral berhubungan dengan manusia lain. Konten tersebut memberikan pesan moral bahwa belajar untuk mendisiplinkan diri agar terhindar dari marabahaya, dengan mendisiplinkan diri maka menjaga dan menghargai ajakan atau perintah orang lain bukan menjadi paksaan melainkan kesadaran. Salah satu manfaat dari disiplin diri adalah membentuk karakter pribadi yang baik dan semua aktivitas akan berjalan dengan lancar apabila kita menjadi orang yang disiplin. Pada masa pandemi ini, penerapan disiplin di dalam mayarakat akan dapat memberikan manfaat yang besar terhadap pulihnya kondisi masyarakat menjadi lebih sehat dan berakhirnya masa pandemi.

Data 3: PM/WA/3.03

Kutipan "Saatnya kita lockdown hawa nafsu, Mensterilisasi dosa-dosa, Mumpung ada PSBB (Pahala Shaum Berskala Besar)"

Berdasarkan konten yang terdapat di status WA termasuk dalam kategori nilai moral hubungan manusia dengan Tuhan. Pesan moral yang terdapat pada kutipan tersebut adalah, pesan untuk menjaga hawa nafsu manusia di saat berpuasa maupun dikehidupan biasanya, seharusnya umat manusia lebih mempersiapkan bekal untuk nanti di akhirat bukan untuk menuruti hawa nafsu. Dalam Al Qur'an telah jelas diperintahkan untuk menjalankan semua perinyah Allah dan menjauhi segala larangan-Nya. Dengan kita tetap menjaga iman, maka ketenangan akan datang dan imun tubuh kita akan tetap terjaga dengan baik dan tidak mudah terserang penyakit.

Data 4: PM/FB/4.04

Kutipan: "Nyong pada tetep nang puskesmas Kedungbanteng demi rika-rika. Tulung rika pada tetep nang umah. Demi nyong pada."

Berdasarkan kutipan di Facebook termausk dalam kategori nilai moral berhubungan dengan manusia lain. Pesan moral yang terdapat dalam kutipan tersebut adalah pesan untuk menjaga tata tertib untuk tetap di rumah untuk meringankan beban tim medis (garda terdepan) dalam mengatasi pandemi. Masyarakat dihimbau untuk tidak keluar rumah, kecuali untuk hal-hal yang sangat penting. Sebab dengan tetap di rumah saja kana dapat memutus mata rantai penyebaran covid-19, sehingga pandemi segera berakhir dan bisa hidup dennga normal kembali.

Data 5: PM/IG/5.05

Kutipan: "Kalian tetap di rumah untuk kami, Kami tetap bekerja untuk kalian"

Berdasarkan kutipan yang terdapat di Instragram, termasuk dalam nilai moral hubungan diri sendiri dengan manusia lain. Pesan moral yang disampaikan oleh nakes terdapat dalam kutipan tersebut adalah lebih meningkatkan lagi 
kesadaran dari diri untuk diri sendiri, orang lain, semua lapisan masyarakat, dan para nakes yang sedang berjuang di garda terdepan. Banyak nakes yang terpapar covid 19 karena merawat pasien yang positif.

Data 6: PM/FB/6.06

Kutipan: "Seakan corona lebih menakutkan dari neraka. Kalian berebut masker karena takut terdampak virus corona. Andai Allah SWT tampakkan neraka, niscaya mereka berebut hijab untuk tutup aurat".

Berdasarkan kutipan yang terdapat dalam konten FB termasuk dalam kategori nilai moral hubungan manusia dengan Tuhan. Pesan moral yang terdapat dalam kutpan tersebut adalah mengingatkan kita dimanapun kita tetap ingatlah untuk menutup aurat kita, bahkan sehelai rambutpun tetap akan ada hisabnya, apalagi apabila sebagian tubuh kita dan rambut kita terjuntai terpampang dilihat banyak orang. Dalam agama Islam, bahwa sudah jelas dalam Al Qur'an disebutkan bagi wanita muslim diwajibkan menutup aurat. Bagi menera yang melaksanakan perintah Allah SWT dengan menutup aurat jaminannya adalah masuk surge, sedangkan bagi mereka yang tidak menutup aurat akan masuk neraka. Adapun aurat yang dimaksud adalah menutup dari ujung rambut hingga ujung kaki. Covid-19 dirasa oleh sebagain orang menjadi sesuatu yang lebih menakutkan dari neraka, sehingga banyak yang tidak mengindahkan aturan agama dengan menutup aurat namun lebih sibuk memikirkan pandemi covid-19.

Data 7: PM/WA/7.07

Kutipan: "Pantang pulang sebelum corona tumbang"

Berdasarkan kutipan yang terdapat di WA termasuk dalam kategori hubungan manusia dengan manusia lain. Pesan moral yang dapat kita peroleh dari kutipan tersebut adalah turut andil membantu penekanan jumlah kasus positif covid-19 dengan cara tetap berada di rumah dan tetap mematuhi protokol kesehatan. Dalam rangka menekan jumlah masyarakat yang positif covid-19, para nakes diharapkan untuk dapat lebih berjiwa sosial dan bekerja dengan penuh tanggungjawab. Bahkan para nakes rela berjam-jam menggunakan baju hazmat ketika bertugas. Baju hazmat yang digunakan kurang lebih selama 7 sampai 8 jam non stop dan hal tersebut sangat membuat nakes kelelahan karena ketidaknyamanannya menggunakan hazmat tersebut. Selain itu, pesan moral juga ingin disampaikan kepada masyarakat adalah jangan mengucilkan para nakes di lingkungannya tempat tinggalnya, ketika ada nakes yang meninggal tidak diterima dipemakaman umum yang iasa digunakan untuk memakamkan jenazah masyarakat pada umumnya. Sejatinya mereka adalah pahlawan yang berani bertaruh nyawa dan jauh dengan keluarga, demi merawat pasien positif covid-19.

Data 8: PM/IG/8.08

Kutipan: "Ojo metu nak njobo. Nang njero wae Mas.."

Kutipan tersebut termasuk dalam kategori nilai moral hubungan manusia dengan manusia lain. Pesan moral yang kita dapat dari kutipan tersebut adalah pesan untuk selalu meningkatkan kesadaran diri demi semua orang yang berada di sekitar kita. Pemerintah dan tim medis telah banyak melakukan berbagai solusi untuk menghadapi pandemi covid-19 meski belum tahu akan sampai kapan semua akan berakhir. Untuk itulah, setidaknya kita mulai dari diri sendiri dalam menjaga kesehatan.

\section{Data 9: PM/WA/9.09}

Kutipan "\#tidak mudik bukan tak ingin bertemu tapi demi masa depanmu."

Berdasarkan kutipan yang terdapat dalam WA termasuk dalam kategori hubungan manusia dengan diri sendiri. Pesan moral yang terdapat dalam kutipan tersebut adalah untuk tetap menjaga ketertiban yang menjadi kewajiban kita demi saudara-saudara agar tidak terpapar covid-19. Larangan mudik oleh Pemerintah semata-mata adalah dilakukan untuk memutus mata rantai penularan covid-19. Apalagi resiko yang akan ditimbulkan ketika mudik adalah banyak orang tua di Desa yang sangat rentan dengan virus covid-19. Oleh karena itu, lebaran pada tahun ini kita mencoba untuk bersabar tidak mudik, akan tetapi masih bisa bersilaturahmi secara virtual.

Data 10: PM/IG/10.10

Kutipan "Daripada di rumah sakit, apalagi di rumah duka, lebih baik di rumah saja. Jangan keluar, jangan tertular, jangan nularin"

Berdasarkan kutipan tersebut termasuk dalam nilai moral hubungan manusia dengan manusia lain. Pesan moral yang diperoleh dari kutipan tersebut adalah tingkatkan protokol kesehatan dan ikuti anjuran dari pemerintah untuk tetap di rumah saja. Upaya masyarakat untuk tetap di rumah saja menjadi sesuatu yang sangat membantu Pemerintah dalam menyelesaikan pandemi. Banyak hal yang dapat dilakukan dengan tetap di rumah saja, diantaranya tetap produktif dan melaksanakan kegiatan WFH serta dapat lebih dekat dengan keluarga dan mendekatkan diri kepada Tuhan.

Data 11: $\mathrm{PM} / \mathrm{FB} / 11.11$ 
Kutipan: "Kamu di rumah ya, agar tau rasanya titip rindu lewat doa"

Kutipan tersebut termasuk dalam kategori hubungan manusia dengan Tuhan. Pesan moral yang terdapat dalam kutipan tersebut adalah pertemuan belum tentu sebagai kebahagiaan, bahkan jika kita mensyukuri sebenarnya doa terbaiklah yang menjadi kebahagiaan terutama bagi mereka semua tenaga medis dan para garda terdepan yang jauh dengan keluarganya. Beberapa nakes dan garda terdepan lainnya bahkan tidak sempat untuk bertemu dengan keluarganya sebagai bentuk pengurangan penularan covid-19, maka dari itu mereka memang harus siap untuk berjarak untuk semantara demi keluarga di rumah, begitupun keluarga di rumah. Nakes juga manusia yang memiliki rindu untuk bertemu dan berkumpul dengan keluarga. Hanya doa yang dapat mempersatukan rindu mereka. Melalui doa juga mereka saling menguatkan, sebab para nakes juga merasa khawatir akan membawa dampak negatif dan banyak yang tidak berani pulang bertemu dan memeluk keluarganya. Sehingga hanya doalah yang saling menguatkan mereka untuk tetap sabar dan ikhlas dalam menjalankan tugas dengan penuh tanggungjawab.

\section{Data 12: PM/IG/12.12}

Kutipan"Stop penyebaran sebar kebaikan"

Kutipan tersebut termasuk dalam kategori hubungan manusia dengan manusia lain. Pesan moral yang terdapat dalam kutipan tersebut adalah dirumah saja bukan berarti kita tidak bisa menyebar kebaikan. Karena untuk saat ini berada di rumah adalah alah satu bentuk penyebaran kebaikan untuk mencegah penularan covid-19. Pandemi mengajarkan kita banyak hal, diantaranya sebagai bentuk kepedulian kepada sesama dengan gerakan $3 \mathrm{M}$. Implementasi dari gerakan $3 \mathrm{M}$ berupa mencuci tangan dengan sabun, memakai masker dan menjaga jarak apabila dilaksanakan dengan baik akan dapat menghentikan penyebaran virus covid-19. Serta dalam rangka menjaga dan meningkatkan imun, ada baiknya mari kita berlomba-lomba melakukan kebaikan.

\section{Data 13: $\mathrm{PM} / \mathrm{FB} / 13.13$}

Kutipan "Jarak menguatkan kita \#stop penyebaran"

Berdasarkan kutipan tersebut termasuk dalam kategori nilai moral manusia dengan manusia lain. Pesan moral yang terdapat dalam kutipan tersebut adalah tidak selamanya yang berdekatan membawa kebahagiaan. Ada kalanya jarak menjadi penguat daya tubuh kita agar terhindar dari paparan virus Corona. Jaga jarak menjadi salah satu hal yang efektif diterapkan dalam masa pandemi ini. Menghindari kerumunan yang hanya akan mendatangkan lebih banyak lagi korban postitif covid-19. Serta saling mendoakan adalah cara kita untuk saling menjaga baik diri sendiri, keluarga maupun orang lain.

\section{Data 14: $\mathrm{PM} / \mathrm{FB} / 14.14$}

Kutipan "Tak saling bertatap wajah tapi saling mendoakan"

Berdasarkan kutipan tersebut termasuk dalam kategori hubungan manusia dengan manusia lain. Pesan moral yang terdapat dalam kutipan tersebut adalah doa merupakan salah satu komunikasi terbaik untuk dia dan kepada Tuhan. Karena salah satu dengan doalah kita mampu membantu saudara yang terdampak pandemi. Tatap muka dapat dilakukan secara virtual dalam kegiatan pembelajaran daring maupun WFH, selain itu dapat dilakukan dengan saling mendoakan kepada sesama manusia.

Data 15: PM/FB/15.15

Kutipan "Pahlawan Corona sebenarnya adalah orang yang tetap di rumah. Bantu kami dengan tetap di rumah" Kutipan tersebut termasuk dalam kategori nilai moral hubungan manusia dengan diri sendiri. Pesan moral yang terdapat dalam kutipan tersebut adalah disiplinkan diri demi diri sendiri dan orang lain. Jika kita disiplin ikuti protokol kesehatan kita dapat dikatakan mampu mencegah diir sendiri dan orang lain terpapar covid-19. Setiap hari bahkan setiap detik selalu ada korab covid-19 yang jumlahnya semakin terus bertambah. Untuk meminimalisir hal tersebut, ada baiknya bagi masyarakat yang tidak berkepentingan untuk tetap di rumah saja. Melakukan banyak hal positif di rumah atau jika akan keluar rumah tetap jaga protokol kesehatan. Ketika kita tetap di rumah saja, kita menjadi bagian dari pejuang covid-19, yaitu pahlawan untuk minimal diri sendiri dan keluarga kita. Semoga dengan tetap di rumah saja, korban positif covid-19 dapat segera menurun dan tidak banyak lagi masyarakat yang menjadi korbannya.

Data 16:PM/IG/16.16

Kutipan "Let's Stay Home"

Kutipan tersebut termasuk dalam kategori nilai moral manusia dengan manusia lain. Meski ditulis dalam Bahasa Inggis, artinya sangat jelas yaitu ajakan untuk di rumah saja. Pesan moral yang terdapat dalam kutipan tersebut adalah tetaplah pada wilayah atau tempat yang aman dan menjauhkan dari wabah atau bahaya. Virus corona sangat 
berbahaya karena penyebarannya yang sangat cepat terutama di tempat-tempat umum. Apabila kita di rumah saja, maka kita akan meminimalisir penggunaan tempat umum. Cukuplah untuk mereka yang bekerja di luar rumah dalam rangka memenuhi nafkah keluarga. Bagi masyarakat yang masih bisa melakukan aktivitas WFH dna belajar secara daring di rumah saja. Hal tersebut akan sangat membantu memutus mata rantai penyebaran covid-19.

\section{PENUTUP}

Hasil penelitian menunjukkan terdapat 16 data pesan moral tang terdapat dalam beberapa konten media sosial bermuatan covid-19. Berdasarkan data penelitian tersebut, diperoleh sebanyak 2 data pesan moral kategori nilai moral manusia dengan diri sendiri misalnya mengingatkan untuk melaksanakan 3M, tetap di rumah saja dan larangan mudik. Selanjutnya, diperoleh sebanyak 11 data pesan moral kategori hubungan manusia dengan manusia lain diantaranya menjadi terang dalam kegelan, jarak saling menguatkan kita, menjadi pahlawan untuk diri dan masyarakat. Tiga dari sekian banyak pesan moral tersebut sangat mendasar sebagai bentuk himbauan kepada orang lain, sebab pandemi ini tidak akan berakhir apabila kita tidak saling menguatkan satu sama lain. Terakhir diperoleh sebanyak 3 data pesan moral kategori nilai moral manusia dengan Tuhan diantaranya seakan corona lebih menakutkan dari neraka dan lockdown hawa nafsu, serta menetralisir dosa-dosa. Seakan bumi ingin menyampaikan bahwa usianya yang semakin tua dan banyak manusia yang selama ini menyia-nyiakan waktunya hanya untuk mengejar dunia dan meninggalkan Tuhan. Bagi masyarakat yang dapat mengambil hikmah dari pandemi ini, maka ia akan segera melakukan banyak hal positif untuk mendekatkan diri dengan Tuhan.

\section{DAFTAR PUSTAKA}

Aristiawan, D. (2020). Courage And Modestyas The Attributes Of Moral Value In The Novel Of The Old Man And The Sea. Journal of Languages and Language Teaching, 8(2), 139-152.

Beerthuizen, M. G., \& Brugman, D. (2013). Moral value evaluation: A neglected motivational concept in externalizing behaviour research. In Handbook of Moral Motivation (pp. 365-384). Brill Sense.

Firwan, M. (2017). Nilai Moral Dalam Novel Sang Pencerah Karya Akmal Nasrey Basral. Jurnal Bahasa dan Sastra, 2(2), 49-60.

Moleong. (2012). Metodologi Penelitian Kualitatif. Bandung: PT Remaja Rosdakarya.

Nurgiyantoro, B. 2013. Teori Pengkajian Fiksi. Yogyakarta: Gadjah Mada University Press.

Susana, F. L. (2016). Analisis Struktur Dan Nilai-Nilai Moral Yang Terkandung Dalam Cerpen Ten Made Todoke Karya Yoshida Genjiro (Doctoral dissertation, Universitas Diponegoro). 